\title{
Business Taxation in an Emerging Economy: Analysing Corporate Tax Incidence
}

\author{
Samiksha Agarwal ${ }^{1}$ \& Lekha Chakraborty ${ }^{2}$ \\ ${ }^{1}$ Former research intern at NIPFP, New Delhi, India \\ ${ }^{2}$ Associate Professor, NIPFP and Visiting Professor American University, India \\ Correspondence: Lekha Chakraborty, Associate Professor, NIPFP and Visiting Professor American University, India
}

Received: May 1, 2018 Accepted: February 27, 2019 Online Published: March 24, 2019

doi:10.5539/res.v11n2p8 URL: https://doi.org/10.5539/res.v11n2p8

\begin{abstract}
This paper estimates the incidence of corporate taxes in an emerging economy -India- using the data from 5,666 business firms listed in the Bombay Stock Exchange (BSE) and the National Stock Exchange of India (NSE) for the period 2000-15. Using the dynamic panel models, we find that capital bear the burden of corporate taxation relatively more than the labour. Our findings highlight that the effective tax rate is higher for the small corporate firms than the gigantic firms. The tax policy implications for strengthening the wage bargaining frameworks is insignificant as we found the wage determination in India is mostly outside the purview of fiscal policy practices. Further research is required to understand whether less incidence of corporate taxation on wages in India is due to base erosion and profit shifting.
\end{abstract}

Keywords: corporate tax incidence, dynamic panel, factor mobility, labour, capital, business taxation

JEL Codes: C33; H22; H25

\section{Introduction}

The corporate tax incidence has significant policy implications for the progressivity of the tax system. The International Monetary Fund (2019) in their policy paper "Corporate Taxation in the Global Economy" has highlighted the macro-criticality of the corporate tax incidence, its cross-country spillovers and the vulnerability due to base erosion and profit shifting activities (BEPS). In an open economy, higher corporate taxes lead to lower capital formation so that labour productivity and wages decline, shifting the tax burden to workers (Harberger, 1962). However, empirical evidence is inconclusive whether the incidence of corporate tax falls on capital or labour or is shared between capital and labour.

Fuest, Peichl and Seigloch (2017) highlights that the cross-country studies on corporate tax incidence (such as Hassett and Mathur, 2006; Felix, 2007; Desai, Foley and Hines, 2007; Clausing, 2013; Azemar and Hubbard, 2015) failed to defend their assumptions on common trend, while single-country design studies ( such as Dwenger, Rattenhuber and Steiner, 2011; Arulampalam, Devereux and Maffini, 2012; Liu and Altshuler, 2013) have ignored the firm specific variables to explain the variation in corporate tax incidence. Our paper contributes to the single-country design literature, by focusing on India, incorporating the firm specific dimensions of the corporate sector.

Unlike the recent single-country studies by Fuest, Peichl and Seigloch (2017) in the context of Germany, and Serrato and Zidar (2016) in USA, which capture the "within country variations" through statutory municipal taxes and the State-level corporate taxes using spatial equilibrium frameworks, we focus on federal corporate tax incidence at the firm level in the context of India. The unit of analysis is not subnational entities in our study because in India the corporate tax is federal and there is no variation in corporate tax across States or municipalities. We bring heterogeneity in the models by incorporating the variables relate to firm level behaviour.

Our paper uses data from 5,666 corporate firms in India (listed on the Bombay Stock Exchange [BSE] and the National Stock Exchange of India [NSE]) from 2000-2015 and analyzes the impact of corporate tax on the capital and labor employed by corporations.

\section{Theoretical and Empirical Review of the Literature}

The empirical research on the corporate incidence are mainly twofold in design: a set of cross-country analysis of effects of taxation on capital and labour mobility from high-tax countries to low-tax countries; and another set of single-country 
research design of the intertemporal effects of business taxation burden on capital and labour, taking into consideration the "within" effects, either at firm level or at subnational government levels. Our study belongs to the latter category of single-country effects of taxation across time and captured with the business firms as the unit of analysis.

Fuest, Peichl and Seigloch (2017), one of the recent single-country research design studies, has estimated the tax incidence for heterogeneous labour categories to analyse whether higher corporate taxes reduce wages most for the low-skilled, women, and young workers. They found that the average pass-through on wages was of the extent $51 \%$. They found that corporate tax was progressive in Germany. Piketty and Saez (2007) also analysed the progressivity of corporate taxation in the context of USA. However, these studies mentioned that the impact of firm level determinants are beyond the scope of their analysis, due to the complications in data. Our paper analyses the corporate tax incidence incorporating the firm level determinants.

Auerbach (2005) reviews "what we know from economic theory and evidence about corporate tax incidence" and highlights that one-dimensional incidence analysis across labour categories can be relatively uninformative as it misses the element timing, and he flagged that it is more meaningful to analyse the tax incidence relates to the path of economy over time. In a seminal paper, Harberger (1962) analyses the corporate tax incidence within a closed economy with two sectors - corporate and non-corporate, where capital bears the burden of business taxation. However, in an open economy, higher corporate taxes decrease capital investment, and thereby labour productivity and wages (Akerlof and Yellen, 1990; Bradford 1978 and Kotlikoff and Summers 1987, Amiti and Davis, 2010). In a cross-country design, the corporate capital moves from high-tax countries to low-tax ones, reducing the capital-labor ratio in the former and leading to a lower marginal product of labor and lower wages. At the same time, low-tax countries experience higher capital-labor ratios, a higher marginal product of labor, and hence higher wages (Auerbach, 2006 and Gravelle, 2013).

Randolph (2006) conducts a study in USA on the basis of Harberger's model. Assuming an open economy, the paper asserts that domestic owners shift much of the burden of the corporate tax onto capital owners abroad. Using data from 65 countries over 25 years, Hassett and Mathur (2006) focus on the long-term impact of higher corporate taxes on wages. The paper finds that higher taxes depress wages. Moreover, the findings suggest that not only domestic but international tax rates also affect domestic wages. This significant relationship between corporate taxes and wages is tested using the fixed effects technique. Felix (2007) tests the relationship between taxes and the burden on capital and labor. Using data for 19 countries from 1979-2002, the paper finds that a one percent higher corporate tax leads to 0.7 percent lower wages after controlling for observable worker characteristics. The paper concludes that as the capital tax rate increases, the burden falls both on labor and capital, with labor bearing slightly more than half of this burden. Arulampalam, Devereux, and Maffini (2007) use company-level European data to estimate the wage effects of tax burdens that differ between firms. The results show that firms with greater tax obligations pay lower wages. Also the estimates imply that labor bears close to 100 percent of the corporate tax burden in the long run.

Desai, Foley, and Hines (2007) estimate wage and interest rate sensitivity to corporate tax rates for a four-year sample of US multinational firm affiliates in OECD countries in the years 1989, 1994, 1999, and 2004. Finding the relative burden of the corporate tax, they constrain the total burden shares to one using the seemingly unrelated regression technique. They find that labor bears between 45 percent and 75 percent of the total burden. Clausing (2012) compares OECD countries to find the effect of corporate taxes on wages. Contrary to the previous empirical literature, the paper finds no evidence of linkages between corporate taxes and wages. A thorough review of the theoretical literature, showing a probable link between the two, is in contrast with the empirics of the paper, which reveals no links between corporate taxes and wages. Carroll (2009) uses cross-sectional state-level data from 1970-2007 to investigate the relationship between corporate taxes and wages at the state level while controlling for both state and time effects. The paper finds a significant relationship between the two and concludes that a 1 percent increase in the average state and local corporate tax rate can lower real wages by 0.014 percent. One of the few papers in the Indian context is by Shome (1978), which explores the effect of a marginal change in the corporate tax on wages in the economy. In a general equilibrium setting, the incidence of corporate tax is tested for the period 1971-72. The findings suggest that a part of the burden of corporate taxes are shifted to laborers and that there is a need to alter the tax base, as the purpose of the corporate tax is in fact to tax capital income and not labor. We take the literature forward by incorporating the firm level specificities in a single country design, and capture the incidence of corporate taxation over time.

\section{Interpreting Data}

The period of analysis is 2000-2015 and includes 5,666 Indian corporate (Bombay Stock Exchange [BSE] and the National Stock Exchange of India [NSE] listed) firms. The source of the data is the Prowess IQ database provided by the Centre for Monitoring Indian Economy (CMIE). The tax rates and budgetary announcements relate to corporate taxation are culled out from Union Budget documents of India. 
Table 1 reveals that the business firms with profits before taxes (PBT) above Rs 500 crores contribute to 60.63 per cent of corporate tax revenue. However, it is also evident that the effective tax rate is only 22.88 per cent for these gigantic business firms (with PBT greater than 500 crore), as compared to 29.37 per cent effective tax borne by the companies with profit before tax up to one crore. Any tax reforms in corporate sector will therefore have redistributive effect on small firms.

Table 1. Effective Tax Rates of Corporate Sector in India, 2015

\begin{tabular}{|c|c|c|c|c|c|c|}
\hline $\begin{array}{l}\text { Sl. } \\
\text { No. }\end{array}$ & Profit Before Taxes & $\begin{array}{c}\text { Share in Profits } \\
\text { before taxes (in \%) }\end{array}$ & $\begin{array}{l}\text { Share in Total } \\
\text { Income (in \%) }\end{array}$ & $\begin{array}{c}\text { Share in Total } \\
\text { Corporate } \\
\text { Income Tax } \\
\text { Liability ( \%) }\end{array}$ & $\begin{array}{l}\text { Ratio of Total } \\
\text { Income to } \\
\text { Profits Before } \\
\text { Taxes (in \%) }\end{array}$ & $\begin{array}{c}\text { Effective Tax Rate } \\
\text { (in \%) (Profit to Tax } \\
\text { Ratio) }\end{array}$ \\
\hline 1 & Less than Zero & 0 & 0.58 & 0.47 & & \\
\hline 2 & Zero & 0 & 6.54 & 2.81 & & \\
\hline 3 & 0-1 Crore & 2.73 & 3.38 & 3.25 & 95.39 & 29.37 \\
\hline 4 & 1-10 Crore & 6.76 & 7.54 & 7.4 & 85.44 & 26.99 \\
\hline 5 & 10-50 Crore & 9.17 & 9.08 & 9.48 & 76.26 & 25.52 \\
\hline 6 & 50-100 Crore & 5.16 & 5.01 & 5.26 & 74.83 & 25.14 \\
\hline 7 & 100-500 Crore & 15.55 & 14.56 & 15.12 & 72.00 & 23.97 \\
\hline 8 & Greater than 500 Crore & 60.63 & 53.31 & 56.21 & 67.66 & 22.88 \\
\hline 9 & All Companies & 100 & 100 & 100 & 76.94 & 24.67 \\
\hline
\end{tabular}

Note: 1 crore (or 100 lakhs) is equivalent to 10 million

Source: Budget Document 2016-17, Ministry of Finance, Budget Division, Government of India

A tax reform in corporate sector to rationalize the tax structure without tax exemptions would also mean effective tax rate going up for those paying lower than the intended statutory rate (Chakraborty and Chakraborty, 2016). The statutory tax rate for corporate sector is as high as 35 per cent. The budgetary announcement in Union Budget of India 2018-19 is a right step in policy direction to reduce the corporate tax rate to 25 per cent only for those firms with turnover up to Rs 250 crores.

\section{The Model Specification and Stylized Facts}

The model specification for impact of corporate taxation (c) on both capital (k) and labor (l) is as follows.

$k_{i t}=\delta k_{i, t-1}+\beta c_{i t}^{\prime}+u_{i t}$

$l_{i t}=\delta l_{i, t-1}+\beta c_{i t}^{\prime}+u_{i t}$

These two regression equations are now treated as separate equations and give the efficiency effects of corporate taxation, incorporating the control variables. The dynamic relationship is characterized by the inclusion of a lagged dependent variable among the regressors. The coefficients from these equations explain the efficiency effects of an increase in the corporate tax on capital and labor. The most important independent variable is the effective corporate tax $\left(c_{i t}\right)$ of the firms. The effective corporate tax to which the firms are subjected is the computed as corporate taxes paid divided by the profit before tax (PBT), which is available directly from the database. A point to be noted here is that a heterogeneity is intrinsic to the observed average tax rate, as it is a function of both statutory corporate tax rates and firm responses to the tax system and its incentives. The lack of variations in statutory corporate tax variable over the years, in single-country research design studies of incidence, is a concern among researchers. One way is to incorporate "tax reforms" to bring in variations. However, in Indian context, there is no high frequency reforms in corporate taxation. The corporate taxes in India also does not vary across subnational governments. Yet another way to bring in heterogeneity is to incorporate the firm's behavioral variables. We have opted in our models, the second option. Prima facie, the relationship between capital and labour with corporate tax should be negative. With the imposition of the corporate tax, the capital formation in the business firms decrease, which further affects the marginal product of labor and hence lower wages. However, following Desai, Foley, and Hines (2007), the independent variables used in our models are log forms of "one minus effective corporate tax". Hence, the expected signs of the coefficients of all three proxies for capital and labour should be positive. In the models, $\ln (1-\mathrm{c})$ captures the coefficient of incidence of corporate tax (c) on capital and [(1-s)/s $\left.)^{*} \ln (1-\mathrm{c})\right]$ captures the effect of corporate tax incidence on labour, where $s$ is the labor share of output defined as $w \mathrm{~L} / \mathrm{Q}$, calculated by dividing 
the compensation to employees (wL) by the total income of the firms (Q). Three proxies are used for the capital variable $(\mathrm{K})$, namely, return on equity (ROE), return on debt (ROD), and gross fixed assets (GFA). ROE is the rate of return received by the shareholders from the profits of the firm after taxes have been paid. It is computed as the ratio of profit after tax to the average net worth, with both values in millions. ROD is the interest rate paid to the debt holders by the firm and is calculated by dividing interest paid by the sum of the long-term and short-term borrowing of the firms, with all figures in millions. The data for long-term and short-term borrowing was available only from 2011-15, therefore the analysis for this indicator is restricted. The GFA of the firm were directly available and are measured in millions. The GFA model is to analyse whether corporate tax has negative effects on capital formation of the firms. The variable used for proxy the labour is the wages paid by the firms. The "compensation to employees" is available in CMIE dataset. All variables are used in the natural $\log$ in the regression models. The heterogeneous firm specific cost variables for infrastructure (INFRA) - power, fuel and water - and raw materials (RW) are also added in the models.

The firm specific cost variables relate to infrastructure - power, fuel, and water charges - incurred by the firms, and the raw materials costs are also available from CMIE dataset. Moreover, only supply-side variables in wage determination model are used rather than demand-side variables. For instance, demand side variables like professional skills and education status are not included as explanatory variables in the wage determination analysis, though it is known to have significant impacts. The unit of analysis of our wage determination model is firm level, not individuals, and therefore the demand side variables are not included for the complications with data consistency.

\section{Econometric Modeling}

Our paper analyzes the influence of corporate tax on capital and labour, integrating the firm-specific variables on the corporate firms' behaviour. To estimate the effect of corporate taxes on capital and labor, we use the one-step generalized method of moments (GMM) by Arellano and Bond (1991) for the estimation of dynamic panel datasets. We have large cross-sectional and small time-series units, corrected for endogeneity issues.

We consider the equation:

$y_{i t}=\delta y_{i, t-1}+\beta x_{i t}^{\prime}+u_{i t}$ where $\mathrm{i}=1 \ldots \mathrm{N}$ and $\mathrm{t}=1 \ldots \mathrm{T}$.

where $u_{i t}=\mu_{i t}+\vartheta_{i t}$, where $\mu_{i t} \sim \operatorname{IID}\left(0, \sigma_{u}^{2}\right)$ and $\vartheta_{i t} \sim \operatorname{IID}\left(0, \sigma_{\vartheta}^{2}\right)$ are independent of each other. The inclusion of the lagged independent variable renders the OLS estimates biased and inconsistent, even if the $\vartheta_{i t}$ are not serially correlated. This is due to the correlation between the lagged dependent variable and the error term. In case of the fixed effects estimator, the within transformation wipes out $\mu_{i t}$ but $y_{i, t-1}$ is still correlated with $\bar{\vartheta}_{l}$ by construction. Hence the fixed effects estimator will be biased and consistent only when $\rightarrow \infty$. Therefore, when $\mathrm{N}$ is large and $\mathrm{T}$ fixed, the within estimator is biased and inconsistent. The random effects estimator will also be biased in a dynamic panel data model. A first difference transformation of the model was suggested by Anderson and Hsiao (1981). This first differencing was used to get rid of $\mu_{i}$ and then the instrumental variable (IV) estimation procedure would be used; however, the above method leads to consistent but inefficient estimates of the parameters.

Arellano and Bond (1991) proposed a GMM procedure that is more efficient than the Anderson and Hsiao (1982) estimator. The methodology used by Arellano and Bond (1991) argued that additional instruments can be obtained if the orthogonality conditions between the lagged values of $y_{i t}$ and the disturbances $\vartheta_{i t}$ are used. Our methodology can be illustrated with the help of a simple autoregressive model with no regressors, as follows:

$y_{i t}=\delta y_{i, t-1}+u_{i t}$ Where $\mathrm{i}=1 \ldots \mathrm{N}, \mathrm{t}=1 \ldots \mathrm{T}$, and $\mathrm{u}_{\mathrm{it}}=\mu_{\mathrm{it}}+\vartheta_{\mathrm{it}}$, with $\mu_{\mathrm{it}} \sim \operatorname{IID}\left(0, \sigma_{\mathrm{u}}^{2}\right)$ and $\vartheta_{\mathrm{it}} \sim \operatorname{IID}\left(0, \sigma_{\vartheta}^{2}\right)$ independent of each other and among themselves. In order to get consistent estimates, the individual effects are first eliminated by first differencing the equation to obtain:

$$
y_{i t}-y_{i, t-1}=\delta\left(y_{i, t-1}-y_{i, t-2}\right)+\left(\vartheta_{i t}-\vartheta_{i, t-1}\right)
$$

When $\mathrm{t}=3$, we have:

$$
\mathrm{y}_{\mathrm{i} 3}-\mathrm{y}_{\mathrm{i} 2}=\delta\left(\mathrm{y}_{\mathrm{i} 2}-\mathrm{y}_{\mathrm{i} 1}\right)+\left(\vartheta_{\mathrm{i} 3}-\vartheta_{\mathrm{i} 2}\right)
$$

In this case, $y_{\mathrm{i} 1}$ is a valid instrument, since it is highly correlated with $\left(\mathrm{y}_{\mathrm{i} 2}-\mathrm{y}_{\mathrm{i} 1}\right)$ and not correlated with $\left(\vartheta_{\mathrm{i} 3}-\vartheta_{\mathrm{i} 2}\right)$ as long as $\vartheta_{\text {it }}$ are not serially correlated. For $\mathrm{t}=4$,

$$
\mathrm{y}_{\mathrm{i} 4}-\mathrm{y}_{\mathrm{i} 3}=\delta\left(\mathrm{y}_{\mathrm{i} 3}-\mathrm{y}_{\mathrm{i} 2}\right)+\left(\vartheta_{\mathrm{i} 4}-\vartheta_{\mathrm{i} 3}\right)
$$

In this case, $y_{i 2}$ as well as $y_{i 1}$ are valid instruments for $\left(y_{i 3}-y_{i 2}\right)$, since both $y_{i 2}$ and $y_{i 1}$ are not correlated with $\left(\vartheta_{\mathrm{i} 4}-\vartheta_{\mathrm{i} 3}\right)$. Adding valid instruments in this fashion for period $\mathrm{T}$, the set of valid instruments becomes 
$\left(\mathrm{y}_{\mathrm{i} 1}, \mathrm{y}_{\mathrm{i} 2} \ldots \ldots . \mathrm{y}_{\mathrm{i}, \mathrm{T}-2}\right)$. Let $\mathrm{w}$ be the matrix of all instruments of individual $\mathrm{i}$, so pre-multiplying the difference equation in the vector form with the matrix of all instruments gives:

$$
\mathrm{W}^{\prime} \Delta \mathrm{y}=\mathrm{W}^{\prime}\left(\Delta \mathrm{y}_{-1}\right) \delta+\mathrm{W}^{\prime} \Delta \vartheta
$$

Now, if we perform generalized least squares on this model, we will get the Arellano and Bond (1991) one-step consistent GMM estimator.

The dynamic effects of corporate tax on capital and labour are given in Tables 2 and 3 . The effects of business taxation on capital is found to be higher than that on labour. The econometric estimates show that an increase in the corporate tax by 1 percent will lead to a fall in the GFA by 0.0534 percent. Similarly, an increase in the corporate tax will result in a decrease in the return on equity by 0.6027 percent. The impact of corporate tax on interest paid on debt is insignificant.

Table 2. Dynamic effects of corporate taxation on capital

\begin{tabular}{|c|c|c|c|c|c|c|c|}
\hline $\begin{array}{l}\text { Dependent Variable/ } \\
\text { Independent Variable }\end{array}$ & Constant & $\begin{array}{c}\text { Lagged } \\
\text { Dependent } \\
\text { Variable }\end{array}$ & $\begin{array}{l}\ln \\
(1-c)\end{array}$ & $\ln (W)$ & $\begin{array}{c}\ln \\
(\text { INFRA })\end{array}$ & $\begin{array}{c}\ln \\
(\mathbf{R W})\end{array}$ & Obs. \\
\hline $\ln ($ GFA) & $\begin{array}{c}1.1201 \\
(0.0393) \\
\end{array}$ & $\begin{array}{l}0.7591 * \\
(0.0095) \\
\end{array}$ & $\begin{array}{l}0.0534 * \\
(0.0117) \\
\end{array}$ & $\begin{array}{l}0.0421^{*} \\
(0.0082)\end{array}$ & $\begin{array}{c}0.0484 * \\
(0.0054)\end{array}$ & $\begin{array}{l}0.0301 * \\
(0.0038) \\
\end{array}$ & 30665 \\
\hline $\ln (\mathrm{ROE})$ & $\begin{array}{c}-1.683 \\
(0.0864) \\
\end{array}$ & $\begin{array}{l}0.2696^{*} \\
(0.0146) \\
\end{array}$ & $\begin{array}{l}0.6207^{*} \\
(0.0427)\end{array}$ & $\begin{array}{l}-0.2192^{*} \\
(0.0235) \\
\end{array}$ & $\begin{array}{c}-0.0043^{*} \\
(0.0209) \\
\end{array}$ & $\begin{array}{l}0.1787^{*} \\
(0.0152) \\
\end{array}$ & 19471 \\
\hline $\ln ($ ROD $)$ & $\begin{array}{l}-3.1747 \\
(0.2391)\end{array}$ & $\begin{array}{l}0.2942 * \\
(0.0435)\end{array}$ & $\begin{array}{c}0.0129 \\
(0.0572)\end{array}$ & $\begin{array}{l}0.2075^{*} \\
(0.0488)\end{array}$ & $\begin{array}{l}0.1005^{*} \\
(0.0346)\end{array}$ & $\begin{array}{l}0.0266 \\
(0.024)\end{array}$ & 5121 \\
\hline
\end{tabular}

Note: * significant at the 1 percent level, ** significant at the 5 percent level, and $* * *$ significant at the 10 percent level.

Source: (Basic data), CMIE PROWESS data

The coefficients of corporate tax in the labour models are relatively of less magnitude than capital models. The increase of 1 per cent in corporate tax would lead to decline in wages to the extent of only around 0.002 to 0.005 per cent (Table 3).

Table 3. Dynamic effects of corporate taxation on labour

\begin{tabular}{|c|c|c|c|c|c|c|c|c|c|}
\hline $\begin{array}{c}\text { Dependent } \\
\text { Variable/ } \\
\text { Independent } \\
\text { Variable }\end{array}$ & Constant & $\begin{array}{c}\text { Lagged } \\
\text { dep } \\
\text { variable }\end{array}$ & $\begin{array}{c}((1-s) / s)^{*} \\
\ln (1-c)\end{array}$ & $\ln ($ GFA) & $\ln (\mathrm{ROE})$ & $\ln ($ ROD $)$ & $\ln ($ INFRA) & $\ln (R W)$ & Obs. \\
\hline $\ln (L)$ & $\begin{array}{l}-0.0141 \\
(0.0270) \\
\end{array}$ & $\begin{array}{l}0.7566^{*} \\
(0.0094)\end{array}$ & $\begin{array}{l}0.0017 * \\
(0.0001)\end{array}$ & & $\begin{array}{l}0.0305^{*} \\
(0.0026)\end{array}$ & & $\begin{array}{l}0.1869^{*} \\
(0.0063) \\
\end{array}$ & $\begin{array}{c}0.0926 * \\
(0.0046)\end{array}$ & 21897 \\
\hline $\ln (L)$ & $\begin{array}{l}-0.2237 \\
(0.028) \\
\end{array}$ & $\begin{array}{l}0.6376^{*} \\
(0.0085) \\
\end{array}$ & $\begin{array}{l}0.0015^{*} \\
(0.0001) \\
\end{array}$ & $\begin{array}{l}0.0573 * \\
(0.0075) \\
\end{array}$ & & & $\begin{array}{l}0.2186^{*} \\
(0.0051) \\
\end{array}$ & $\begin{array}{c}0.1130^{*} \\
(0.0036)\end{array}$ & 30585 \\
\hline $\ln (L)$ & $\begin{array}{l}-0.4591 \\
(0.1296)\end{array}$ & $\begin{array}{c}0.621^{*} \\
(0.0283)\end{array}$ & $\begin{array}{l}0.0005^{*} \\
(0.0002)\end{array}$ & & & $\begin{array}{c}0.0053 \\
(0.0052)\end{array}$ & $\begin{array}{l}0.1945^{*} \\
(0.0109)\end{array}$ & $\begin{array}{c}0.0986^{*} \\
(0.0076)\end{array}$ & 5291 \\
\hline
\end{tabular}

Note: * significant at the 1 percent level, $* *$ significant at the 5 percent level, and $* * *$ significant at the 10 percent level.

Source: (Basic data), CMIE PROWESS data

The lack of significant impact of corporate tax on labour needs to be interpreted with caution, in the context of India. Apriori in case with perfect mobility of labour, corporate taxation should not affect labour. But the mobility differentials across various labour categories is beyond the scope of this paper. The migration decisions may depend on wage determination as well as public service provisioning ("voting with feet" to better jurisdictions). An analysis of disaggregating these effects can be a future research. Fuest et al (2017) highlights that gigantic and in particular foreign-owned firms can avoid taxes by shifting profits across jurisdictions or even abroad and if this is relevant, one should observe smaller effects of corporate tax changes for these firms on wages.

\section{Conclusion}

Using the dynamic panel models, this paper estimates the corporate income tax incidence in India. The econometric estimates suggest that capital bears relatively more burden of corporate tax than labour. The effective taxation rate of corporate sector of small firms in India is found to be relatively higher than that of gigantic firms. However, the channels of business taxation on wage determination are found relatively weaker in India. The lack of pass-through of business tax effects on labour can also depend on wage determination mechanisms, though an analysis of these collective bargaining models are beyond the scope of our present paper. The lack of significant link between corporate taxation and wages may also due to profit shifting arrangements. However, this demands further research whether the incidence of corporate taxes 
on wages is lesser due to income shifting to avoid taxes.

\section{References}

Akerlof, G. A., \& Janet, L. Y. (1990). The Fair Wage-Effort Hypothesis and Unemployment. The Quarterly Journal of Economics, 105(2), 255-283. https://doi.org/10.2307/2937787

Amiti, M., \& Donald, R. D. (2010). Trade, Firms, and Wages: Theory and Evidence. Review of Economic Studies, 79(1), 1-36. https://doi.org/10.1093/restud/rdr016

Anderson, T. W., \& Hsiao, C. (1981). Estimation of Dynamic Models with Error Components. Journal of the American Statistical Association, 76(375), 598-606. https://doi.org/10.1080/01621459.1981.10477691

Arellano, M., \& Bond, S. (1991). Some tests of specification for panel data: Monte Carlo evidence and an application to employment equations. The review of economic studies, 58(2), 277-297. https://doi.org/10.2307/2297968

Arulampalam, W., Devereux, M. P., \& Maffini, G. (2007). The Incidence of Corporate Income Tax on Wages. Oxford University Centre for Business Taxation Working Paper No. 07. Oxford: Oxford University Centre for Business Taxation.

Auerbach, A. J. (2006). Who Bears the Corporate Tax? A Review of What We Know. NBER Working Paper No. 11686. Cambridge, MA: National Bureau of Economic Research. https://doi.org/10.3386/w11686

Azemar, C., \& Glenn, H. R. (2015). Country characteristics and the incidence of capital income taxation on wages: An empirical assessment. Canadian Journal of Economics, 48(5), 1762-1802. https://doi.org/10.1111/caje.12179

Carroll, R., \& Prante, G. (2009). Corporate Taxes and Wages: Evidence from the 50 States. Tax Founda.

Chakraborty, P., \& Lekha, C. (2016). Beyond Fiscal Prudence., Economic and Political Weekly, 51(16), 29-32.

Clausing, K. A. (2013). Who Pays the Corporate Tax in a Global Economy. National Tax Journal, 66(1), 151-184. https://doi.org/10.17310/ntj.2013.1.06

Desai, M. A., Foley, C. F., \& Hines, J. R. (2007, December). Labor and capital shares of the corporate tax burden: International evidence. In Conference on who pays the corporate tax in an open economy.

Felix, A. R. (2007). Passing the Burden: Corporate Tax Incidence in Open Economies. Federal Reserve Bank of Kansas City, Working Paper RRWP 07-01. Kansas City, MO: Federal Reserve Bank of Kansas City.

Fuest, C. A. P., \& Siegloch, S. (2017). Do Higher Corporate Taxes Reduce Wages? Micro Evidence from Germany. IZA Discussion Paper $\quad$ No. $7390 . \quad$ VoxEU. Available at: http://voxeu.org/article/incidence-corporate-taxation-and-implications-tax-progressivity

Gravelle, J. C. (2013). Corporate Tax Incidence: Review of General Equilibirum Estimates and Analysis. National Tax Journal, 66(1), 185-214. https://doi.org/10.17310/ntj.2013.1.07

Harberger, A. C. (1962). The Incidence of the Corporation Income Tax. Journal of Political Economy, 70(3), 215-40. https://doi.org/10.1086/258636

Hassett, K. A., \& Aparna, M. (2006). Taxes and Wages. American Enterprise Institute for Public Policy Research Working Paper No.128. Washington, DC: American Enterprise Institute.

International Monetary Fund. (2019). Corporate taxation in the Global Economy”, Policy Paper, February 21, 2019, Washington DC: IMF.

Kotlikoff, L. J., \& Lawrence, H. S. (1987). Tax Incidence. In Handbook of Public Economics. 2, ed. Alan J. Auerbach and Martin Feldstein, 1043-1092. Amsterdam:Elsevier. https://doi.org/10.1016/S1573-4420(87)80011-3

Liu, L., \& Rosanne, A. (2013). Measuring the Burden of the Corporate Income Tax under Imperfect Competition. National Tax Journal, 66(1), 215-237. https://doi.org/10.17310/ntj.2013.1.08

Piketty, T., \& Emmanuel, S. (2007). How Progressive is the U.S. Fed- eral Tax System? A Historical and International Perspective. Journal of Economic Perspectives, 21(1), 3-24. https://doi.org/10.1257/jep.21.1.3

Randolph, W. C. (2006). International Burdens of the Corporate Income Tax. Congressional Budget Office Working Paper Series 2006-09. Washington, DC: Congressional Budget Office.

Sarma, K. S. R. N., \& Thavaraj, M. J. K. (1971). Estimation of Tax Incidence in India. Economic and Political Weekly 6(19), 957-64.

Shome, P. (1978). The incidence of the Corporation Tax in India: A General Equilibrium Analysis. Oxford Economic Papers, New Series 30(March), 64-73. https://doi.org/10.1093/oxfordjournals.oep.a041405 
Suarez, S., Juan, C., \& Owen, Z. (2016). Who Benefits from State Corporate Tax Cuts? A Local Labor Markets Approach with Heterogeneous Firms. The American Economic Review, 106(9), 2582-2624. https://doi.org/10.1257/aer.20141702

\section{Copyrights}

Copyright for this article is retained by the author(s), with first publication rights granted to the journal.

This is an open-access article distributed under the terms and conditions of the Creative Commons Attribution license (http://creativecommons.org/licenses/by/4.0/). 